\title{
First record of the endemic phytophilous cladoceran Celsinotum candango Sinev \& Elmoor-Loureiro, 2010, in Minas Gerais state, in a threatened shallow lake at Serra do Gandarela
}

\author{
Francisco Wagner Moreira ${ }^{1}$, Emerson Silva Dias ${ }^{1}$ \& Eneida Maria Eskinazi Sant'Anna ${ }^{1,2}$ \\ ${ }^{1}$ Universidade Federal de Ouro Preto, Instituto de Ciências Exatas e Biológicas, \\ Departamento de Biodiversidade, Evolução e Meio Ambiente. Laboratório de Ecologia Aquática. \\ Campus Morro do Cruzeiro, CEP 35400000, Ouro Preto, MG, Brazil. \\ ${ }^{2}$ Corresponding author: Eneida Maria Eskinazi Sant'Anna, e-mail: eskinazi@iceb.ufop.br
}

MOREIRA, F.W., DIAS, E.S., SANT'ANNA, W.M.E. First record of the endemic phytophilous cladoceran Celsinotum candango Sinev \& Elmoor-Loureiro, 2010, in Minas Gerais state, in a threatened shallow lake at Serra do Gandarela. Biota Neotropica. 15(4): e0052. http://dx.doi.org/10.1590/1676-0611-BN-2015-0052

\begin{abstract}
This study describes the occurrence of the phytophilous cladoceran Celsinotum candango, which has been considered, up to now, an endemic species of the Brazilian Cerrado, with only two previous records in the wetlands of Brasilia, Federal District. The cladoceran has now been registered at Coutos Lake ("Lagoa dos Coutos"), an altitudinal, temporary shallow lake, located in ironstone outcrops at Serra do Gandarela, Minas Gerais state. This mountain ridge was recently turned into an integral protection conservation unit, the Gandarela National Park. However, many shallow lakes, including this one, were excluded from the delimited area of the park, and are now at risk of disappearing due to expansion of mining activities. The information provided here reveals the importance of these shallow lakes to aquatic biodiversity, and reinforces the need for the inclusion of these rare aquatic ecosystems into the recently created Gandarela National Park.
\end{abstract}

Keywords: Cladoceran, Celsinotum, occurrence, shallow lake, Serra do Gandarela, Minas Gerais.

MOREIRA, F.W., DIAS, E.S., SANT'ANNA, W.M.E. Primeiro registro do cladócero fitófilo endêmico Celsinotum candango Sinev \& Elmoor-Loureiro, 2010, no estado de Minas Gerais, em uma lagoa ameaçada da Serra do Gandarela. Biota Neotropica. 15(4): e0052. http://dx.doi.org/10.1590/1676-0611-BN-2015-0052

Resumo: O objetivo deste estudo foi descrever a ocorrência do cladócero fitófilo Celsinotum candango, uma espécie considerada, até o momento, endêmica do cerrado brasileiro, com registros anteriores em apenas duas áreas úmidas de Brasília (Distrito Federal). O cladócero foi agora encontrado na Lagoa dos Coutos, uma lagoa temporária de altitude, localizada em área de afloramento ferruginoso da Serra da Gadarela, no estado de Minas Gerais. A Serra foi recentemente transformada em uma unidade de conservação (Parque Nacional do Gandarela). Entretanto, esta lagoa, além de outras, foi excluída da área delimitada para o Parque, e está agora sob risco de desaparecer, em função da expansão da atividade de mineração. As informações fornecidas no presente estudo revelam a importância dessas lagoas para a biodiversidade aquática, e reforçam a necessidade de inclusão desses raros ecossistemas aquáticos na recém-criada unidade de conservação do Parque Nacional do Gandarela.

Palavras-chave: Cladócero, Celsinotum, lagoa, Serra do Gandarela, Minas Gerais.

\section{Introduction}

Small lakes are vital inland bodies of freshwater, representing around 30 percent of the global surface area of standing water (Downing et al. 2006; Ewald et al. 2012). These wetlands are recognized as ecosystems of extreme ecological importance, but are nevertheless still neglected in terms of conservation (Maltby 1991; Downing 2010). Altitudinal shallow lakes have also been considered crucial, not only because of the exclusive species they can support, but also due to the suitable environment they provide for the interaction amongst distinct animal groups such as insects, amphibians, birds, mammals, and several others, hence contributing to the maintenance of local and regional diversity (Wiggins et al. 1980; Williams 2006). These shallow environments are usually colonized by aquatic macrophytes, which contribute to their high environmental heterogeneity by diversifying habitats and ecological niches (Drew et al. 2005, Van Der Valk 2012, Lukacs \& Finlayson 2010).

When compared to the organisms associated to the macrophytes in these humid areas, the phytophilous cladoceran can be considered a group of exceptional diversity. Although they harbor up to $70 \%$ of the known cladoceran species (Elmor-Loureiro 2000, Forró et al. 2008), it was only recently that wetlands of the Brazilian Cerrado were added to research aimed at taxonomic knowledge for these organisms. As a result, new species were described and new geographic patterns 
were established for the phytophilous cladoceran (Sinev \& Hollwedel 2002, Serafim-Junior et al. 2003, Elmoor-Loureiro 2007, Elmoor-Loureiro et al. 2009, Sousa et al. 2014 and others).

The freshwater cladoceran Celsinotum candango was described very recently (Sinev \& Elmoor-Loureiro 2010), having its first occurrence in Brazil attributed to a phytophilous community in a shallow pond in Brasília, Federal District. So far, there is only one more record of the species, also in a shallow pond from the Cerrado wetlands (Sousa et al. 2013). In our study, we describe the presence of this species in a temporary shallow lake, "Lagoa dos Coutos" (Lake Coutos), located in ironstone outcrops at Serra do Gandarela (southern portion of the Espinhaço mountain range). This is the third record in Brazil and first in Minas Gerais of the cladoceran Celsinotum candango.

Serra do Gandarela is one of the most important synclines of the Minas Gerais central region and it houses several springs that supply water to the Belo Horizonte metropolitan region, including streams and creeks of special class water (ICMBio 2010). Serra do Gandarela is also an important ecological corridor, joining the Caraça region to two important basins: Rio Doce/Piracicaba and São Francisco/Rio das Velhas. According to Jacobi and Carmo (2008a), there is a very high level of plant diversity at Serra do Gandarela. This is a result of mineral and topographical heterogeneity of the outcrops, which creates distinct microhabitats, resulting in a unique association of extremely adapted plants. These adaptations can include metallophytes or, at least, metal-tolerant plant species (Jacobi et al. 2007).

Due to the occurrence of these unique environments, high biodiversity and endemic levels, and imminence of impact associated with mining activity, in addition to other anthropic activities, the creation of the National Park of the Serra do Gandarela was proposed and then promulgated on October $13^{\text {th }}, 2014$ through a Decree-Law. However, only 31.4 out of the 38 hectares initially proposed by the Instituto Chico Mendes de Conservação da Biodiversidade (ICMBio) were considered, excluding rare shallow lakes from complete protection, among them, the Coutos Lake. Mining activity has expansion projects in these unprotected areas, which will inevitably result in the extinction of these aquatic ecosystems. We hope that the information of our study will contribute to reinforce the need to prioritize the preservation of such unique aquatic ecosystems that are still not very well known, but potentially relevant to aquatic biodiversity.

\section{Material and Methods}

The Coutos Lake (1959'6.54" S; 433' $\left.4.75^{\prime \prime} \mathrm{W}\right)$, is a temporary shallow lake (as described by Williams 2006), located in an ironstone outcrops area, in the municipality of Barão dos Cocais, at about $100 \mathrm{~km}$ from the state capital, Belo Horizonte. This lake is located in the Rio Doce basin, at $1072 \mathrm{~m}$ above sea level, under highland subtropical climate with dry winters and rainy summers. It is a shallow pond with $0.65 \mathrm{~cm}$ depth average, reaching $1.5 \mathrm{~m}$ during the rainy period, until complete dryness in August. Figure 1. During our study (from January to June/2013), water temperature ranged from 29 to $18{ }^{\circ} \mathrm{C}$, presenting higher variation during the summer $(25.6 \pm 1.4)$. The Coutos Lake can be considered oligotrophic (chlorophyll $a$ averaging $<5$ g. $\mu \mathrm{L}^{-1}$ ), with neutral to acid waters ( $\mathrm{pH}$ ranging from 7.46 to 4.77 ), and low conductivity (from 70 to $120 \mu \mathrm{S} . \mathrm{cm}^{-1}$ ) (Dias, 2014). Since it is a shallow lake, it presents dense macrophyte banks throughout its whole extension, with patches dominated by Eleocharis minima. Several other species of macrophytes have also been found in Coutos Lake, such as Nymphoides indica, Polygonum mesneirianum, Helanthium tenellum, Utricularia sp., and Egeria najas (Dias 2014).

Specimens of the cladoceran Celsinotum candango were found among samples of macrophytes collected in January $15^{\text {th }}$, February $15^{\text {th }}$ and June $19^{\text {th }} 2013$, during a decomposition experiment. The macrophytes samples were collected through the use of "litter bags", with dimensions of $10 \times 20 \mathrm{~cm}$ (Petersen \& Cummins 1974). The specimens were extracted from the samples under a stereomicroscope, preserved in $70 \%$ alcohol, and identified according to description given by Sinev \& Elmoor-Loureiro (2010). All specimens were measured using an eyepiece-micrometer and deposited in the aquatic invertebrate collection of Aquatic Ecology, Evolution and Conservation Laboratory at the Federal University of Ouro Preto. Water temperature $\left({ }^{\circ} \mathrm{C}\right)$, conductivity $\left(\mu \mathrm{S} . \mathrm{cm}^{-1}\right)$ and $\mathrm{pH}$ were obtained with a Horiba (model U-50) analyzer.

\section{Results and Discussion}

The genus Celsinotum was initially considered endemic to Australia (Frey, 1991); however, it has been registered in other places lately, amplifying its distribution. In Brazil, C. laticaudatum had only been found in the Northern part of the Brazilian Amazon (Smirnov \& Santos-Silva 1995), while C. candango had only been found in the Brazilian Cerrado (Sinev \& ElmoorLoureiro 2010, Sousa 2013). This paper now presents the first record of $C$. candango in the state of Minas Gerais and, furthermore, its first record in an altitudinal temporary lake on ironstone outcrops.

\section{Family Chydoridae Stebbing, 1902}

Celsinotum candango Sinev and Elmoor-Loureiro 2010 (Figure 2A-D).

\section{Family Chydoridae Stebbing, 1902}

\section{Celsinotum candango Sinev \& Elmoor-Loureiro 2010} (Figure 2A-D).

According to the description of Sinev and Elmoor-Loureiro (2010), Celsinotum candango clearly differs from all other species of the genus in proportions of the postabdomen, as the postanal portion is only $1.2-1.3$ times longer than anal one in all other species. C. candango also differs from the other Brazilian species $C$. laticaudatum Smirnov and Santos-Silva 1995 in longer spine on basal segment of antenna exopodite (about 2/3 length of middle segment of antenna), in the shape of the postabdomen (it is only weakly narrowing distally, distal part of postanal portion is almost rectangular) and in the postabdominal denticles, in this species distalmost denticles are long and single (Sinev \& Elmoor-Loureiro 2010).

The four $C$. candango individuals found in Coutos Lake (adult parthenogenetic females) were small, with a maximum length of $0.65 \mathrm{~mm}$. The individuals were found in water temperature ranging from 24.7 to $18^{\circ} \mathrm{C}$, conductivity from 

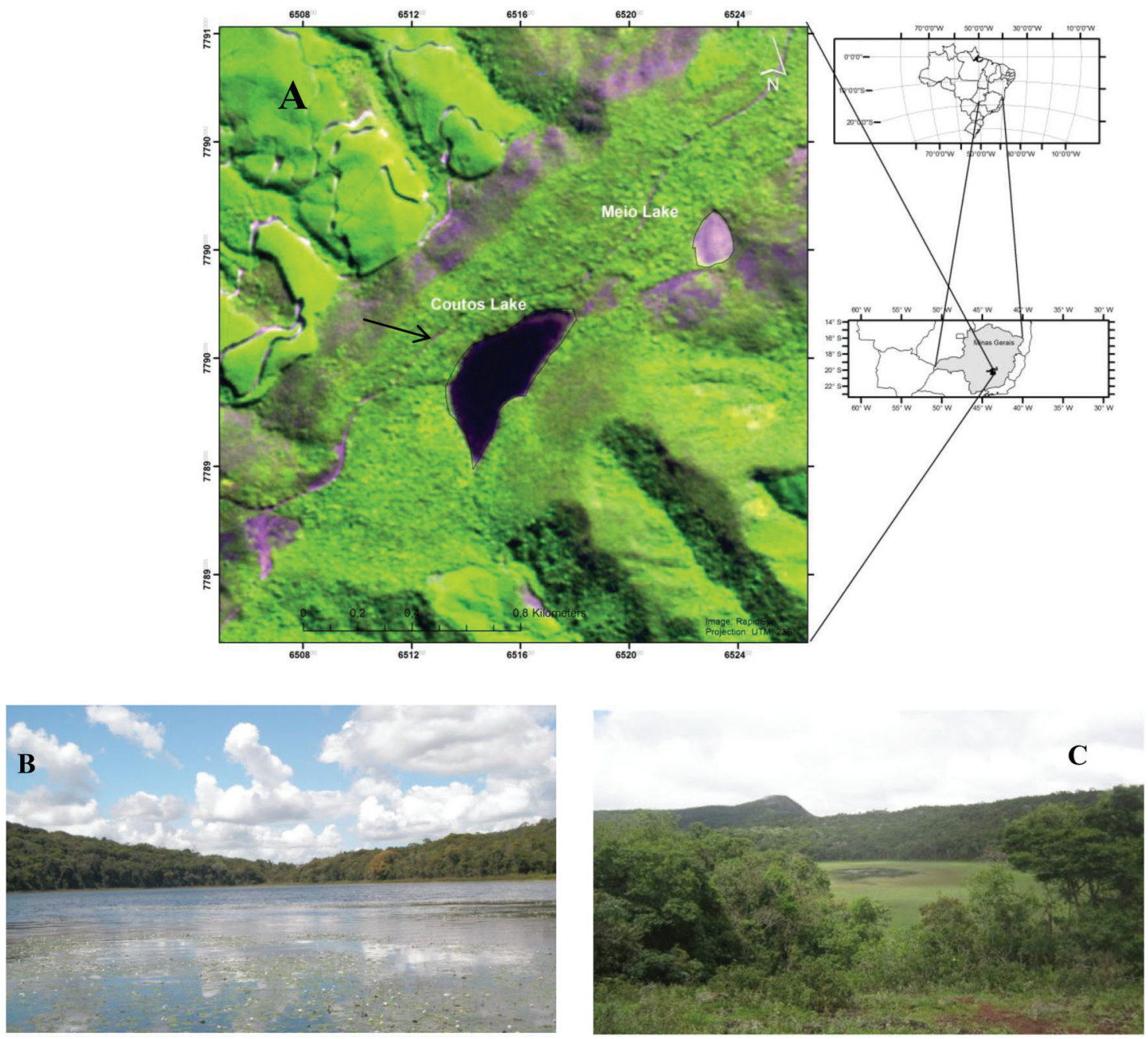

Figure 1. Map of Gandarela Ridge location and Lagoa dos Coutos. Gandarela Ridge location (A). Coutos Lake panoramic view during rainy period (January/2012) (B). Coutos Lake during dry period (August/2013) (C).

109 to $91 \mu \mathrm{S} . \mathrm{cm}^{-1}$ and lake water with acid feature ( $\mathrm{pH}$ from 6.4 to 5.3) Table 1 . The specimens presented the characteristic postabdomen, with postabdominal claw from $65-70 \mu \mathrm{m}$ in length and postanal margin with clusters of small distalmost denticles in each, besides the spine on basal segment of exopodite of antenna as shown in Figure 2. We did not find ephippial forms from $C$. candango, in spite of the occurrence of other cladocerans resting eggs, and the temporary characteristic of Coutos Lake. The species is considered endemic to the Brazilian Cerrado wetlands (Sousa et al. 2014), and presents restricted geographic distribution with ecological preference for shallow environments, dominated by macrophytes.

Traditionally, most studies in aquatic ecology have been directed to 'permanent' (i.e., hydroperiod $>1$ year) lentic and

Table 1. Limnological variables at Coutos Lake during the sampling of Celsinotum candango specimens, in 2003.

\begin{tabular}{lccc}
\hline & Conductivity $\left(\mu \mathbf{S . c m}^{-\mathbf{1}}\right)$ & $\mathbf{p H}$ & Temperature $\left({ }^{\mathbf{0}} \mathbf{C}\right)$ \\
\hline January & 109 & 5.7 & 24.9 \\
February & 100 & 6.4 & 24.7 \\
June & 91 & 5.3 & 18.0 \\
\hline
\end{tabular}

lotic systems. As a result, we know more about communities in permanent waters than we do about those in temporary ones and have less evidence to protect these unique, endangered habitats than for other systems (Schwartz \& Jenkins 2000). The results of our study reinforce the importance of small ponds to aquatic biodiversity, by congregating plants diversity, environmental heterogeneity, and invertebrate assemblages with specific habitat requirements, such as phytophilous cladocerans. All these features can enhance the occurrence of exclusive species in these temporary aquatic ecosystems.

Coutos Lake can nowadays be considered a threatened aquatic ecosystem in the Gandarela ridge. The intense expansion of mining activity in the region is considered one of the greatest threats to the integrity of Serra do Gandarela ecosystems (Jacobi \& Carmo 2008b, Carmo et al. 2012). The creation of the Gandarela National Park did not reach these areas of extreme relevance to the preservation of species and ecosystems in ironstone outcrops of the Serra, not even shallow lakes that still deserve further research in order to describe their biodiversity. The record of this recently discovered cladoceran species reveals that there probably is still much more to find in these unique ecosystems that are now critically threatened of disappearing. 

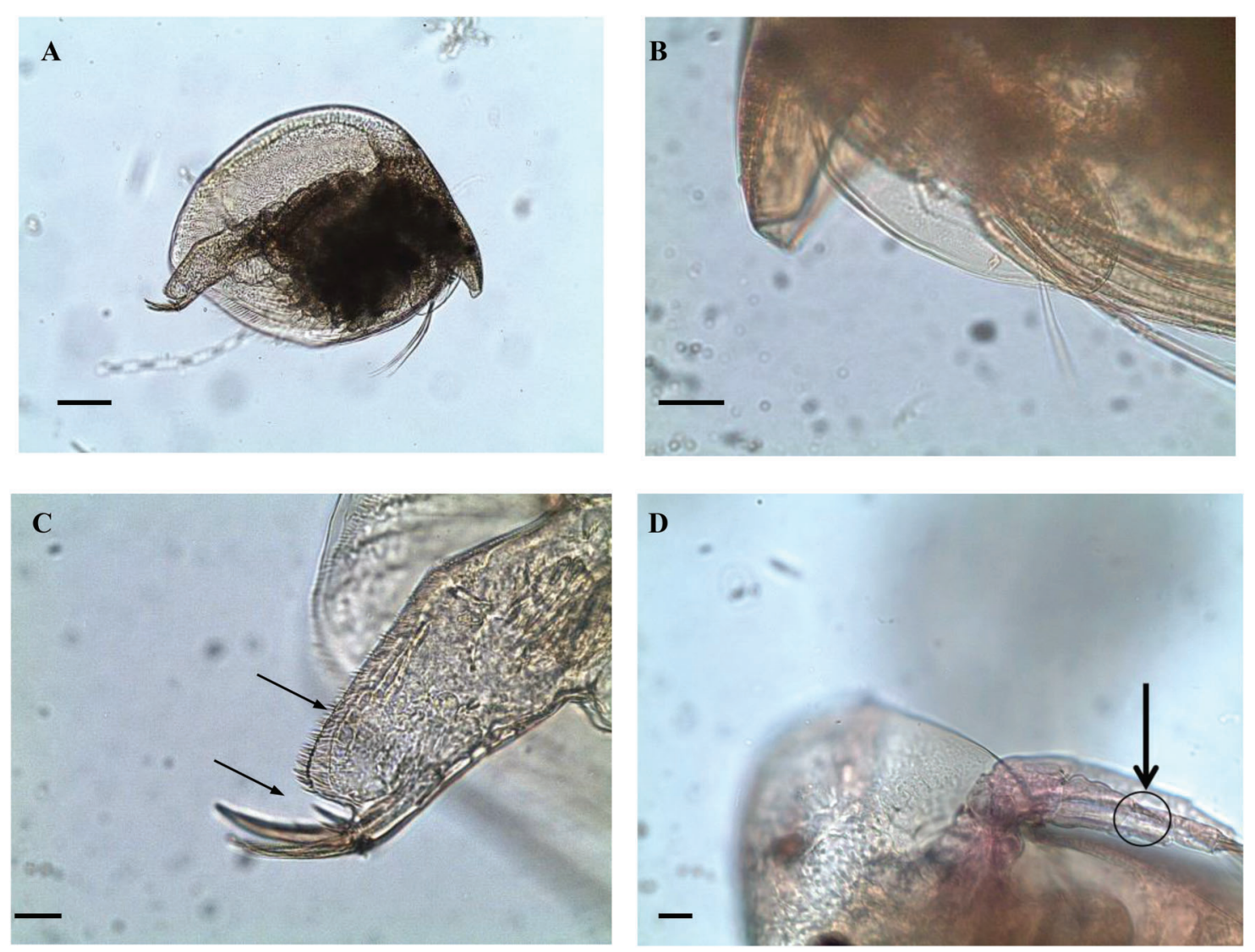

Figure 2. Aspects of Celsinotum candango registered in Coutos Lake, Serra da Gandarela, MG. (A) General aspect of the individual. (B) Detail of rostrum and labrum . (C) Postabdomen. Detail of postanal margin of postabdomen, lateral setules and terminal claw; (D). Detail of antenna and spine on basal segmento of exopodite. Scale bars $0.1 \mathrm{~mm}$ for A- B, $0.01 \mathrm{~mm}$ to C and D.

\section{Acknowledgments}

We are very grateful to Gleicidele Tamires Tenório Pedrosa for macrophytes identification. The authors thank CAPES (Coordenação de Aperfeiçoamento de Pessoal de Nível Superior) for a fellowship grant to Emerson Dias. Sincere thanks to Transport Sector of the Federal University of Ouro Preto, for extensive assistance during field collections. For specimen confirmation we would like to thank Dr. Lourdes M.A. Elmoor-Loureiro. Funding to this project was provided by FAPEMIG (CRA - APQ-01767-11). EMES is a researcher of the Brazilian National Council for Scientific and Technological Development (CNPq). We thank the reviewers for constructive comments to the manuscript.

\section{References}

CARMO, F.F., CARMO, F.F., CAMPOS, I.C. \& JACOBI, C.M. 2012. Cangas: ilhas de ferro estratégicas para a conservação. Ciência Hoje (295): 48-53.

DIAS, E.S. 2014. A decomposição de macrófitas não é influenciada pela comunidade de invertebrados: um estudo de caso em uma lagoa temporária na Serra do Gandarela (MG). Dissertação de Mestrado, Universidade Federal de Ouro Preto, Ouro Preto.

DOWNING, J.A., PRAIRIE, Y.T., COLE, J.J., DUARTE, C.M., TRANVIK, L.J., STRIEGL, R.G., McDOWELL, W.H., KORTELAINEN, P., CARACO, N.F., MELACK, J.M. \& MIDDELBURG, J.J. 2006. The global abundance and size distribution of lakes, ponds and impoundments. Limnol. Oceanog., 51(5): 2388-2397, http://dx.doi.org/10.4319/lo.2006.51.5.2388
DOWNING, J.A. 2010. Emerging global role of small lakes and ponds: little things mean a lot. Limnetica 29(1): 9-24.

DREW, W.M. EWEL, C.K, NAYLOR, R.L. \& Sigrah, A. 2005. A tropical freshwater wetland: III. Direct use values and other goods and services. Wetl. Ecol. Manag. 13(6): 685-693, http://dx.doi.org/10.1007/ s11273-005-0966-8

EWALD, N., KALETTKA, T. \& BRENDONCK, L. 2012. Eyes of the landscape - Value, conservation and management of European ponds. Limnologica 42(4): 251-253, http://dx.doi.org/10.1016/j.limno. 2012.09.001

ELMOOR-LOUREIRO, L.M.A. 2000. Brazilian cladoceran studies: where do we stand? Nauplius 8(1): 117-131.

ELMOOR-LOUREIRO, L.M.A. 2007. Phytophilous cladocerans (Crustacea, Anomopoda and Ctenopoda) from Paraná river Valley, Goiás, Brazil. Rev. Bras. Zool. 24(2): 344-352, http://dx.doi.org/10.1590/ S0101-81752007000200012

ELMOOR-LOUREIRO, L.M.A., SANTOS-WISNIEWSKI, M.J. \& ROCHA, O. 2009. New records of Parvalona parva (Crustacea, Anomopoda: Chydoridae) from Brazil, with description of the male. Zoologia 26(2): 369-373, http://dx.doi.org/10.1590/S198446702009000200022

FORRÓ, L., KOROVICHINSKY, N.M., KOTOV, A.A. \& PETRUSEK, A. 2008. Global diversity of cladocerans (Cladocera; Crustacea) in freshwater. Hydrobiologia 595(3):177-184, http://dx.doi.org/10.1007/ s10750-007-9013-5

FREY, D.G. 1991. A new genus of alonine chydorid cladocerans from athalassic saline waters of New South Wales, Australia. Hydrobiologia 224(1): 11-48, http://dx.doi.org/10.1007/BF00006361

ICMBIO. Instituto Chico Mendes de Conservação da Biodiversidade. 2010. Parque Nacional da Serra da Gandarela. Estudos técnicos 
para a criação de unidade de conservação federal. Relatório técnico. 103p.

JACOBI, C.M., CARMO, F.F., VINCENT, R.C. \& STEHMANN, J.R. 2007. Plant communities on ironstone outcrops: a diverse and endangered Brazilian ecosystem. Biodiver. Conserv. 16(4): 2185-2200, http://dx.doi.org/10.1007/s10531-007-9156-8

JACOBI, C.M. \& CARMO, F.F. 2008a. The contribution of ironstone outcrops to plant diversity in the Iron Quadrangle, a threatened Brazilian landscape. Ambio, 37(4): 324-326, http://dx.doi.org/10.1579/ 0044-7447(2008)37[324:TCOIOT]2.0.CO;2

JACOBI, C.M. \& CARMO, F.F. 2008b. Diversidade dos campos rupestres ferruginosos do Quadrilátero ferrífero, MG. Megadiversidade 4(1-2): 25-33.

LUKACS, G.P. \& FINLAYSON, C.M. 2010. An evalutaions of ecological information on Australia's nothern tropical rivers and wetlands. Wetl. Ecol. Manag. 18(5): 597-625, http://dx.doi.org/10.1007/s11273010-9197-8

MALTBY, E. 1991. Wetlands and their values. In: Wetlands, (M. Finlayson \& M. Moser, eds). Facts on File Limited, Oxford, p. 8-17.

PETERSEN, R. C. \& CUMMINS, K. W. 1974. Leaf processing in a woodland stream. Freshwater Biol. 4(1): 343-368, http://dx.doi. org/10.1111/j.1365-2427.1974.tb00103.x

SCHWARTZ, S.S. \& JENKINS, D.G. 2000. Temporary aquatic habitats: constrains and opportunities. Aquatic Ecol. 34(1): 3-8, http://dx.doi.org/10.1023/A:1009944918152

SERAFIM JUNIOR, M, LANSAC-TÔHA, F.A, PAGGI, J.C, VELHO, L.F.M \& ROBERTSON, B. 2003. Cladocera fauna composition in a river-lagoon system of the upper paraná river floodplain, with a new record for Brazil. Brazilian J. Biol. 63(2): 349-356, http://dx.doi.org/10.1590/S1519-69842003000200020

SINEV, A.Y. \& HOLLWEDEL, W. 2002. Alona brandorffi sp. n. (Crustacea: Anomopoda: Chydoridae) -a new species from Brazil, related to A. verrucosa Sars, 1901. Hydrobiologia 472(3): 131-140, http://dx.doi.org/10.1023/A:1016381509999

SINEV, A.Y. \& ELMOOR-LOUREIRO, L.M.A. 2010. Three new species of chydorid cladocerans of submafily Aloninae (Branchipoda: Anomopoda: Chydoridae) from Brazil. Zootaxa 2390: 1-25.

SMIRNOV, N.N. \& SANTOS-SILVA, E.N. 1995. Some littoral anomopods (Crustacea) from Central Amazonia. Hydrobiologia 315(2): 227-230, http://dx.doi.org/10.1007/BF00051952

SOUSA, F.D.R., ELMOOR-LOUREIRO, L.M.A. \& MENDONÇAGALVÃO, L. 2013. Cladocerans (Crustacea, Anomopoda and Ctenopoda) from Cerrado of Central Brazil: Inventory of phytophilous community in natural wetlands. http://www.scielo.br/pdf/ bn/v13n3/1676-0603-bn-13-03-222.pdf. Last access: 06/11/2014.

SOUSA, F.D.R., ELMOOR-LOUREIRO, L.M.A., QUADRA, A. \& SENNA, A.R. 2014. First record of Cladocera (Crustacea: Chydoridae) from Parque Nacional do Itatiatia, Southeastern Brazil. Check List 10(3): 665-668, http://dx.doi.org/10.15560/10.3.665

VAN DER VALK, A.G. 2012. The Biology of Freshwater Wetlands. Oxford University Press, New York, 296p.

WILLIAMS, D. D. 2006. The Biology of Temporary Waters. Oxford University Press, Oxford, 337p.

WIGGINS, G.B., MACKAY, R.J. \& SMITH, I.M. 1980. Evolutionary and ecological strategies of animals in annual temporary pools. Arch. Hydrobiol. Suppl. 58(1): 97-206. 